\title{
The Development of "Enemy Icon" in Speeches of Policy-Makers: Russian Speeches Concerning the War of August 2008
}

\author{
N. Tabeshadze
}

\section{ABSTRACT}

Words can be sharper than bullets. That is why the speeches of politicians are especially important. Language of hatred can be used as a strategic weapon for downgrading the enemy and for building up the desired narrative template followed by whole society. The article focuses on the development of enemy icon with the help of the hated language. Research is based on the content analysis of the speeches made by Russian policymakers after the war of August 2008 concerning Georgia. The article analyzes the content of high rank Russian policy-makers in order to draw general conclusions of the language of hatred used in speeches of policymakers. Given sampling was chosen considering the influence of the speech authors in target society as they define how the historic events are perceived by the society. As a result, the article offers step by step explanation of speech building where one can see particular interest hidden behind certain words and sentences.

Keywords: Enemy, Language of Hatred, Speech-Building

Published Online: January 7, 2022

ISSN: $2736-5522$

DOI: $10.24018 /$ ejsocial.2022.2.1.197

\section{N. Tabeshadze}

Georgian Institute of Public Affairs, Georgia.

(e-mail: nt3154@gmail.com)

\section{INTRODUCTION}

"The wise learn many things from their enemies" - words of Aristophanes seem very relevant for postmodern societies. With opened borders and highly accessible information technologies, countries create the image and the policy-makers try to use opponent's tools in their favor to win the elections and become the part of government. The policy-makers have a very important role in society. They are the selected people by the voting who are expected to serve the community and be of service to the people. This role becomes enhanced when the society goes in the war. The identity of society changes when faced with war destruction. The people try to reform its' own identity. Challenges brought by war make society disoriented and logically, they start to re-assess their own feeling of self. This was especially true in case of August war 2008 because the war brought not only havocs, but also the high number of Internally Displaced People who had difficulties. War already represents Collective Trauma or the event holding especial meaning for country's society. Unexpectedly the lifestyle of the society changes and it might be accompanied by disorientation (La Capra, 2001). Of course, war brought Posttraumatic stress disorder that can be cured by blaming the others in misfortune. It is not the only solution; however, the formation of new identity is most commonly used by politicians to establish their image and authority in the eyes of potential electorate. Generally, symptoms of Posttraumatic Stress Disorder can be revealed in any society which participated in conflict (regardless of the war result). Therefore, the policy-makers become important actors in all of them.

In this article, I will focus on the case of the August war 2008 - a five-day war that took place between Georgia and Russia. My aim is not to discuss the political dimension of this war, but to see how the governments tried to interpret the fact of war as well as actions taken by the governments. Moreover, the aim of the article is to explore the language of hatred as the tool in creating the icon of the enemy. "Enemy" is a strong word, and "emotions associated with the enemy would include anger, hatred, frustration, envy, jealousy, fear, distrust, and possibly grudging respect. As a political concept, an enemy is likely to be met with hate, violence, battle and war (Cottam et al., 2009). As a rule, when the post-war re-identification happens, the opposing force or "the other" becomes very important. Exactly this "other" is demonized and by representing them as "bad" opposed to representing "us" as "heroes", we can rebuild our own identity and at the same time have a scapegoat. In this moment, statements made by policy-makers become very important. They are communicating with people and present the part of society which is framing "our" group and defining who are "others". For them, the governmental moves need justification, while the nation needs someone to blame in misfortunes. This article tries to explore the speeches made by official political elite of Russia while making announcements to see whether they tried to create an icon of enemy or no. And to what extent was Georgia perceived as an enemy by Russian politicians. For the article, I chose only 
the most influential politicians and tried to explore if they follow particular ideology/frame while talking about the enemy.

\section{Methodology, Strategy, Data Source AND APPRoACH}

Methodological strategy includes drawing a comparison between contexts used in speeches of high-rank Russian policy-makers where the language of hatred has been developed. In integrating data, I try to explore different parts of the enemy icon creation based on qualitative analysis, more precisely content analysis, of Russian policy-makers speeches in the case of August War 2008. All of my data will lead to making assumption about the process through using data as evidence. My aim is to integrate generated data technically in order to find similarities in the statements made by Russian policy-makers. For sampling I chose the speeches made by Russian policy-makers which concerns August War 2008 due to the fact that policy-makers create the general political course of the country and they influence overall mood of the audience. This will be a case study mostly focusing on the concrete steps taken by Russian governmental representatives to create the icon of enemy from Georgian government and people in 2008 by using the language of hatred. Discussion of case is based on content-analysis approach which is based on obtaining detailed transcripts of high-rank Russian politicians. As I am going to analyze not only public speeches but also the TV interviews of Russian high rank policy-makers concerning Georgia and its' role in August war of 2008. The materials are obtained from Russian TV channels and Kremlin webpage which makes data reliable and valid (by providing an understanding that translation is proper and done under official confirmation). In order to have effective content analysis, I will create hypothetic sample sentences which will serve as rules for coding and which we will use for decoding certain meanings behind the words said by Russian Policy-makers. By decoding the text by using coding rules, I will try to see the usage of hatred language, frequency of the similar accusations in different speeches and attempt to build the hostile narrative.

Afterward I am going to analyze the content (with content analysis method, this time using Dugin's sentences as coding) of several speeches based on narrative template of Aleksandr Dugin - philosopher, whose influence has been seen on the formation of Russian position. As a result, I hope to achieve step-bystep description of enemy icon creation method, which often is propagandized to population even after the war as well. "As many observers have suggested, Vladimir Putin used the Georgian war as he had used Chechen conflict before, to tighten the screws in Russia, many people argued that Georgian side did the same in our country" (Goble, 2009). So far, statements by Russian politicians declared Russia to have only peacekeeping role in the region. They used to underline that Russia had no interest in conflict and its' aim was to secure peace on the border. However, the announcement of former president of Russia (Medvedev, 2008), which he made on the 12th of August 2008, made clear how Russian politicians saw Georgia in this conflict: "The Georgian leadership, in violation of the UN Charter and their obligations under international agreements and contrary to the voice of reason, unleashed an armed conflict victimizing innocent civilians. The same fate lay in store for Abkhazia. Obviously, they in Tbilisi hoped for a blitz-Krieg that would have confronted the world community with an accomplished fact. The most inhuman way was chosen to achieve the objective - annexing South Ossetia through the annihilation of a whole people." (President of Russia, 2008) By all means, this speech leads to association of Georgia with Nazi Germany introducing the fastwar tactics. Therefore, we can clearly see the attempt of the president Medvedev in promulgating Georgia as an aggressor by coding Nazi German analogy in his speech. The article will further try to explore the speeches of Russian policy-makers in search for the statements or concrete mechanisms of enemy creation.

\section{THEORY AND DISCUSSION}

The paper argues that the theory Russian politicians massively use belongs to Aleksandr Dugin who establishes the language of aggression by these famous theories. More precisely, his 1997 book "Foundations of Geopolitics" is the mandatory reading textbook in the Academy of General Staff in military. Aleksandr Dugin is an influential philosopher in Russia who served as government's adviser. Therefore, he is an interesting theoretician, whose ideas are widely advertised by Russian policy-makers. Textbook created by him calls for anti-American revolution calling for "the battle of the Russian world rule" (Dugin, 2018). Of course, the language of the book, as well as overall ideas given in it influence the reader and put negative context on any powerful European country neglecting some of the states altogether. For example, "Ukraine as a state has no geopolitical meaning, no particular cultural import or universal significance, no geographic uniqueness, no ethnic exclusiveness, its certain territorial ambitions represent an enormous danger for all of Eurasia and, without resolving the Ukrainian problem, it is in general senseless to speak about continental politics". Aleksandr Dugin mentions Georgia as well: "Georgia's independence is unacceptable. Abkhazia and South Ossetia should be incorporated in Russia" (Dugin, 
2018).

Russia's world domination can be achieved by subversion, destabilization, and disinformation spearheaded by the Russian special services. The operations should be assisted by a tough, hard-headed utilization of Russia's gas, oil, and natural resources to bully and pressure other countries (Dunlop, 2004). Considering all above-mentioned facts, I guess it is clear how the aggressive language was established in Russia against its' neighbors. And, of course, this process became more visible during the August war of 2008.

As Dugin mentioned in his scholarly works, the meaning of disinformation and the role of mass media is very big for the society's life, especially during the war. We live in the era of rapid technological advancement and the language of hatred is widely used in the speeches transferred through media to the society. "One of the earlies indications of the importance Moscow attached to the information war in Georgia, and also of the ways in which its actions in that campaign backfired on the Russian authorities, was symbolized by the Russian government's pre-position of journalists in Tskhinvali prior to start of hostilities. The day before Georgia introduced forces into its breakaway region of South Ossetia, there were at least forty-eight Russian journalists there" (Goble, 2009). As we conclude, one of the first steps for information war preparation as well as creation of the enemy icon should be the concentration of mediums in the hotspot. Information sources can provide the established governmental position to the wide audiences, therefore, people become influenced by the slogans and statements of policy-makers.

In his article "Defining Victory and Defeat: The Information War" Paul Goble states five main lesson we can study from the information wars. One of them is especially important for our article:" Defining who is the winner and who is the loser in any conflict is likely to depend far more on the information struggle than on the one involving conventional arms" (Goble, 2009). Of course, in the case of August war 2008 the information war prepared the ground for further announcements of Russian policy-makers which showed Georgia in negative context.

Before the actual warfare it was necessary to equip Russian soldiers with appropriate information about the probable problems. The step taken by Russian government very much follows the idea of Dugin about the creation of disposition or the overall mood towards the enemy. Even before Georgia would become the real war rival, in July 2008 during Kavkaz-2008 military exercises in North Caucasus, Russian soldiers were given a leaflet which said: "Soldier, know your probable enemy!" (Illarionov, 2009). The leaflet gives detailed information about the number of infantry and soldiers as well as provides small introduction to the history of Russian-Georgian relations. It underlines how Georgians refused to have friendly relation with Russia under the Influence of NATO. As we see, Russian policy-makers prepared the ground for creation of enemy icon:

1. First of all, they prepared the mass media for transferring the information to the masses in the country.

2. Then the government prepared the position of soldiers by offering them leaflet about the possible enemy, thereby, using the language of hatred against the country which was not the physical enemy yet.

Considering all that, it will not be surprising that The Russian government continued to develop other messages and slogans against Georgia after the war as well. It was not only during the five-day war that Georgia was made into enemy, but it was a very long process before and after the warfare. The post-war period was heavily loaded by the announcements of Russian politicians commenting on the warfare for Russian media. For more illustration, we can see the post-war announcement of Russian Foreign Affairs minister, Sergey Lavrov: "Georgia after it attacked, as I said, its own regions in the early nineties, accepted that there would be international mechanisms to keep peace in Ossetia and in Abkhazia but not to perpetuate the situation. In both cases international negotiating mechanism has been established with the participation of Georgia, which unfortunately for the last couple of years the Georgian government has been consistently ignoring and asking for something else. You know that people say now "Let's announce immediate ceasefire." But ceasefire was announced two days ago only to be violated by the Georgian forces. The ceasefire is something, which you use when the war has started already. But for the last few months Russia alone has been trying to persuade the Georgian government to deliver on this commitment and to sign a legally binding document not to use force in the Southern Ossetian conflict" (Lavrov, 2008). As expected, this speech underlines the aggressive behavior of Georgian government towards its population and the role of Russia as a defender of citizens. Naturally, Lavrov underlines the Russian peace keeping attempts which has been ignored by Georgian government. Therefore, it can be concluded by the wide audiences that Georgian government did not like the peace keeping initiatives of Russian federation.

Russia's foreign affairs minister Sergey Lavrov dedicated big portion of his speech to Georgia on August 9 in 2008 (Embassy of Argentina in Russian Federation, 2008). "Russia's aim is to keep peace. This is not just Russia's aim; this is Russia's obligation" - declared Russia's first diplomat. After being asked the question about whether the Russians will target certain Georgian spots due to their interest, Lavrov said "No" and explained that "Georgian military budget having increased I think 30 times over the last three 
years, which is being an all-time record.... Georgia is for sure number one arms importer of the world. And now we see these arms being put in action to the detriment of all the civilians, many of whom are Russian citizens." As we see the policy-maker accuses Georgia of purchasing the weapon and using it against Russian civilians calling it a massacre. With his assessment, Russians stopped the aggression at the same time confirming that itself Russia had connection with Russian passport delivery to Georgian territories: "Some 25 million people who used to be the citizens of the Soviet Union, overnight found that they are living in a foreign country. And Parliament of the Russian Federation in 1991 adopted the law saying that whoever was a holder of a Soviet passport has the right to become a Russian citizen.... when people try to blow this particular aspect of the situation - the Russian passports in Ossetia and Abkhazia - out of proportion, I always remind them about a situation in a different country, in Moldova, where huge proportion of the population is getting Romanian citizenship and the EU is quiet". However, after the following answer "Question: Does not Georgia then have the right to control its entire territory? Lavrov: Absolutely" I guess the reader can conclude that on the one hand Russian Policy-maker recognizes the right of the country to control it's territory, but on the other criticizes Georgian government as killer of civilians, organizers of massacre and accuses them of war crimes such as killing of wounded Russian soldiers promising the international action "And the President of the Russian Federation said that those who are responsible for it should be brought to justice and we would be considering using the international law proceedings."

For the reader of this interview Georgia seems very aggressive country, only those who did the follow up of events know about the investigation of International Criminal Court held from 2015 which investigated war crimes against Georgians during the war: "A top prosecutor from ICC in The Hague, Netherlands, Fatou Bensouda announced in October 2015 she wanted to investigate possible crimes committed during the 2008 conflict between Russia and Georgia, noting there was "strong evidence" crimes had been committed during the short but violent war. Bensouda indicated between 51 and 113 ethnic Georgian civilians were killed during a "forcible displacement campaign" conducted by South Ossetia's de facto authorities, with the possible participation of members of the Russian Armed Forces" (Agenda.Ge, 2016). Sergey Lavrov is just one example of the policy-maker creating the narrative for enemy icon creation. As we see the third step on this way might be propagandizing evil character of opposite country and naming it as the main source of violence. Overall, the third step can be summarized as:

3. Creating the negative image of aggressor by accusing the opponent of crime against its own citizens.

Another policy-maker whose speeches we are going to focus on in my article is Dmitry Medvedev, former president and now the prime-minister, who at first warned the world about upcoming problem. And then made additional comments in his speech on 26th of August 2008. President Medvedev's first comment on upcoming problems immediately before the war include one very interesting point. He underlined that "Whatever our colleagues from the alliance may say, NATO countries see Russia as a potential enemy. We can't help getting worried when the circle around our country keeps narrowing as more and more countries join NATO. NATO's expansion clearly poses a threat to the Russian Federation" (Isachenkov, 2018). About Georgia he added: There is an unresolved territorial conflict ... and would they bring such a country into the military alliance? Do they understand the possible implications? It could provoke a horrible conflict" (Isachenkov, 2018). Overall tone of Medvedev's speeches reveal his didactic attitude: not only it shows big concern in relation to Georgia itself, but also in relation to NATO as a hostile organization for the region controlled by Russian peacekeepers. The former president attributes his actions to the desire of security and welfare of the region.

"A decision needs to be taken based on the situation on the ground. Considering the freely expressed will of the Ossetian and Abkhaz peoples and being guided by the provisions of the UN Charter, the 1970 Declaration on the Principles of International Law Governing Friendly Relations Between States, the CSCE Helsinki Final Act of 1975 and other fundamental international instruments, I signed Decrees on the recognition by the Russian Federation of South Ossetia's and Abkhazia's independence. Russia calls on other states to follow its example. This is not an easy choice to make, but it represents the only possibility to save human lives" (President of Russia, 2008). As we see in this case, former president underlines not only the threat of country to its own citizens, but he also mentions wider dimension of threat for whole region. Therefore, Medvedev justifies his moves by emphasizing the threat for the region in case of ignoring potential danger. From speeches of Medvedev, it can be concluded that every step made by Russia as a country was aimed at limiting the aggression of Georgia towards regional states. Unlike Lavrov, Medvedev sees bigger conspiracy in bringing the issue of NATO and naming Georgia as a part of the bigger plan. This might be done because the policy-maker of Russia tries to explain the involvement of Russia in regional issues. It would sound more natural if Russia was defending itself against NATO because otherwise, the proportions of military forces used by Russian policy-makers would be strictly under the question. In case Georgia was announced as the partner of NATO's ambitions in the region, it could be more explainable 
why Russia involved itself in conflict so eagerly.

In his speeches after August, Medvedev underlined the global impact of war not only on Caucasus, but also on the whole world, thereby, confirming our assumption of propagandizing the August was as the opposition of bigger forces, than two countries. "I mean, of course, the situation with which the Russian Federation was confronted in August... I mean the Caucasus crisis. We cannot ignore its consequences, consequences not only for our country but also for the whole global world order" ( Faulconbridge, 2008).

Therefore, we see the fourth point of drawing the enemy icon. The former president of Russia tried to show and promulgate the danger of expanded aggression towards the neighborhood of Georgia.

\section{Show the enemy as a danger to whole region by attributing allies to it.}

Having other forces in the background who support aggression of target country, makes situation more dramatic in the eyes of region citizens, therefore, they fully support the actions taken by their own government in order to stop potential aggressor.

On the 15th of August, another set of announcements made by former president Medvedev undoubtedly attract our attention. His speeches give away very interesting elements of strategic enemy icon creation. More concretely, Medvedev does not only underline the responsibility of Russia towards its own citizen, but also uses historical examples to draw parallels not discussing them in details, but just mentioning similar situations around the world:

"As far as peacekeepers are concerned, of course we are not opposed to having international peacekeepers there. It is not our position on the matter that is the issue. We are carrying out our share of the responsibilities for ensuring security in this very complex region. But the issue is that the Ossetians and Abkhazians themselves trust only the Russian peacekeepers because the events of the last 15 years have shown them that the Russian peacekeepers are the only force able to protect their interests and often their very lives. This is why they see the Russian troops as the only guarantee of their security, and this is something that also has to be taken into account.

I can give you an example from a recent and also very complicated case, that of Kosovo, when Kosovo rejected the participation of peacekeepers under UN mandate and asked for peacekeeper units formed on the basis of a special European Union mandate, and this request of theirs was met. I do not intend to go into an assessment of the situation there, but at the very least, people who face oppression, pressure or genocide have to feel comfortable with the force charged with bringing peace and tranquility to country" (President of Russia, 2008b).

As we see, the Russian policy-maker underlines the historical analogue of Kosovo as the relevant example to show that Ossetia had the same right while fighting against Georgians. Usage of historical examples for creation of particular narrative is often discussed among scholars. As famous author, sociologist Eviatar Zerubavel mentions in his "Time Maps", societies are mnemonic entities (A mnemonic, also known as a memory aid, is a tool that helps you remember an idea or phrase with a pattern of letters, numbers, or relatable associations (Literary Terms, 2015). Of course, societies and, moreover, policymakers need to "develop a general framework that would reveal the fundamental structure of social memory" (Zerubavel, 2003). Zerubavel (2003). identifies six narrative patters which helps the society connect the past and the present: "1. Unilinear patterns of progress, decline, and the "zigzag", which is a change of course; 2. The multilinear pattern of "trees and ladders" that is evident in anthropological or evolutionary discussions of life development; 3 . The circular or cyclical pattern; 4 . The "mountains and valleys" narrative form that emphasizes critical events; 5 . Continuity through place, rituals, relics, imitation and historical analogy; 6. Discontinuity through periodization and collective amnesia" (Zerubavel, 2003). Zerubavel (2003) mentions historical analogy which was used widely in the speeches of Russian policymakers. The first example would be comparison of Georgia to NAZI Germany voiced by Medvedev and the second would be comparison of Ossetia and Kosovo. Of course, those analogues tried to represent the group of "others" or Georgians in a bad light. Georgia represented the icon of enemy which can be related to other negative forces of world history. But is was not all: Of course, the former president of Russia added the role of media in his speeches to create the framework for understanding of conflict: "You know that the tragedy that took place had us all glued to the TV screens and to other media sources and the Internet. I, like any ordinary person, also got some of my information from the media, as well as from the channels I have as President. The information picture that emerged leads me to ask three questions I would like you to reflect on. First, who started the military operations in South Ossetia? Was it the peacekeepers, the Russian troops, or was it the Georgian army? If you look at what is shown on television the answer is not clear, but we know the answer to this question" (President of Russia, 2008b).

Russian policy-makers understood that the population of their country watched Russian media, therefore, they hoped to attract people's attention to the conflict as they saw it. It was the version of August War by Russian political elite's eyes. But this vision was destined for the population of Russia, for potential electorate. These steps would facilitate the increase of trust in government. In this regard we see another sign brought by Dmitry Medvedev: 


\section{Providing historical analogues to compare the enemy to other evil forces of history.}

As we investigated, the speeches by Vladimir Putin offer more insight in enemy icon formation. On August 7, 2012, Vladimir Putin had a meeting with journalists during his trip in Leningrad region. He was asked about the August war and what happened there. President obviously tried to indicate, that Russian reaction was an answer and that Russia has been patient while making a decision of military intervention:

"A decision to use the armed forces is a very serious matter indeed, because it amounts to an order to begin military operations, which means there will be shooting and loss of life. You need to think ever so carefully before making such a decision. This is a very difficult and responsible matter. It was them who launched the attack. We know the subsequent development of events. But let me stress again that deciding to use the armed forces is a very serious matter, and so of course you need to think it through properly first. You always need to think carefully first." The speech of Putin underlines how thoughtful was the step of Russia contrasting it with the position of Georgia which launched an unthoughtful attack. Therefore, Putin tries to underline how serious is Russia regarding the events happening in Caucasus. Vladimir Putin always makes point in reminding his population that threat exists. In 2013 he mentioned that "Everything relating to the protection of the state border is important - there are no minor issues here - but nevertheless we must pay particular attention to the south of the country, to the North Caucasus and cooperation with our colleagues in Central Asian republics in the light of the situation in Afghanistan. In addition, we must pay attention to the Far East and the Arctic" (President of Russia, 2013). Therefore, President makes evident what can be the next step in enemy icon creation process:

\section{Reminding the population about constant threat coming from enemy.}

Policy-makers of the country very often declare about their mission: to protect the nation against upcoming threat. Every government tries to ensure the welfare and security of the citizens. Of course, security issue becomes much promulgated in post-war situation. And in this concrete situation Putin makes an announcement about readiness for the state border protection. This statement gains additional importance in ongoing borderization process: Russia quietly moved one of its borders hundreds of meters further into Georgia, Kremlin troops reportedly moved a border sign hundreds of yards further into occupied territory in South Ossetia (Pasha-Robinson, 2017). By this move we can see that Russian policy-makers still perceive the situation in Caucasus as threatful. Someone might argue that these elements are not purposefully planned and created steps of well-realized politics of country. However, the recent step taken by Russian president proves that his every speech and action carry particular meaning. It is a reminder to the friends and enemies that Putin and other policy-makers remember everything:

"Russian President Vladimir Putin has left off neighbors Ukrainian President Volodymyr Zelenskiy, Georgian President Salome Zurabishvili, and the leaders of Estonia, Lithuania, and Latvia, as well as Poland's head of state among the 41 national leaders to whom he extended New Year's greetings on December 30" (Radio Free Europe Radio Liberty, 2019). Even based on this short extract from news on New Years Eve, we can assume that Russian policy-makers are not friendly with the countries, leaders of which were ignored. In this context we can assume that every speech made by policy-makers, every step they take in relation to undesired neighbors has purposeful character. Looking at the war-time speeches of Russian high elite politicians we understand that the war issue was very seriously used as propaganda. But not only the war-time but even aftermath speeches were full of language of hatred towards the war opponent. Let's take Zhirinovsky and his 2015-year Duma speech: in 2015 Russia decided to recognize Abkhazia and South Ossetia as independent entities. In his speech the Russian policy-maker reveals the language of hatred by accusing the president of Georgia:

"I do not need those, who is going to write for me, copying from encyclopedias and reference books. And then, soldiers are dying. So then, a historical conclusion: When we were accepting Georgia into the composition of the Russian state, advisors were saying: "Your highness, we should not do it". It's time to admit that Tsar Alexander 1st made a mistake. Why did he make a mistake? He was young! Same as Saakashvili. He didn't have brain; he didn't have experience.... Tsar made a mistake 200 years ago, but he corrected it, by not created any national segmentation there! There were Tiflis governorate, Kutaisi, Yerevan and Baku! And silence! And everywhere were sitting Russian general-vicars! Vorontsov and others! That's it! Why Ossetians and Abkhazians should live in composition of Georgia? And Georgia does not want to live in composition of Russia. And there was never any friendship of the peoples! Raise the Soviet Statistics! Only from Soviet Georgia, there was constant outflow of the Russian population! Why are you keeping silent about this?!.... Bush is a puppet! Same as Saakashvili! Dick Cheney - here is the main enemy of humanity today!" (Zahinho, 2015). As we see, the Russian policy-maker actively promotes the idea of guilt of Soviet Union in giving the opportunity to separate from union. Considering his position Georgia should also be blamed in discriminating Russian population. Zhirinovsky's speech fully reflects the interpretation of historical events. His analogue of Saakashvili and Alexander 1st shows that Russians also make mistakes, however, the insult of historical figures by naming them brainless is not entirely ethical. Zhirinovsky also uses historical examples to prove his opinion but unlike the other speakers he underlines 
wider conspiracy against Russian federation which is initiated by particular individuals. Therefore, the next step in forming the enemy icon would be:

\section{Showing that enemy is not alone. There is wider conspiracy with multiple actors.}

Russian policy-makers used to underline this in their speeches; however, Zhirinovsky makes direct statement in blaming concrete individuals for causing the conflict. He accuses several people naming the presidents of Georgia and USA as puppets. Moreover, according to this Russian policy-maker there is a big conspiracy behind the curtain. And, of course, he connects this conspiracy to Russian soldiers and names them as direct victims of mistakes made by policy-makers. Overall tone of his speech is of course aggressive towards Georgian opponents as well as towards Russian colleagues who are blind to see the conspiracy. The final target audience is wider Russian public as the speech was officially shown to several Russian channels. Therefore, not only the people sitting at the parliament meeting but also those sitting in front of the television were listening to the theory of Zhirinovsky.

\section{CONCLUSION}

My initial aim was to show the steps taken by policy-makers in order to create the icon of enemy by introducing coded statements in Russian policy-makers speeches. I chose the case of the August war because of several reasons: first of all, I am the witness of all the events and politicians' announcements that were made during the war as well as in the post-war period. The second reason I chose this case is the date of the war. The August war took place in August 2008 or eleven years ago. The event was almost a decade ago, however, the societies were very influenced by the language of hatred used by policy-makers. Both societies were widely influenced but I chose Russian speeches made by policy-makers because they are showing step by step strategy of enemy icon formation.

Firstly, we saw the basic narrative frame or template created by philosopher Aleksandr Dugin and used by Russian policy-makers as a coding rule for many of their public statements. It gave us better glimpse of the framework Russian Policy-makers would use in their speeches. Only after understanding the main framework, we were able to go to concrete speeches and discuss them based on our hypothetical statements. Dugin's ideas are based on the approach that Russia has the mission to control the region and every tool (including disinformation/misinformation/fake news) can be used. Using the media for spreading the ideas with language of hatred is a common strategy, however, in this concrete case, population was actually prepared beforehand by policy-makers with the booklets named "Soldier, know your probable enemy!" Moreover, sending big number of journalists to Tskhinvali before the war already created an opportunity for misinformation and fake news.

During the war, we saw numerous attempts to create the image of aggressor Georgia attacking its' own citizens. Russia seemed like the peacekeeper in this light. Additionally, Russian Policy-makers made the point in asserting that Georgia was not alone in this conflict referring to its allies. Otherwise the proportionality of the military campaign might be under question. Therefore, Russians tried to accuse not only Georgia but also its' allies of initiating the conflict as well as triggering it. Allies make the enemy stronger so that it becomes a threat for whole region. So, interfering in this situation is also important for Russia as they need to protect themselves in case of potential future threat. During the interpretation of conflict Russian policy-makers also compare Georgia to historical evil forces bringing historical analogues. Aftermath of war has been very active period for political announcements as well. On the verge of upcoming elections (there were presidential elections in 2012) Russian high rank politicians underlined the possibility of future potential threat coming from enemy. With this step wide audience or the population of country would avoid drastic experiments and, most probably, would not change the government radically in order to keep safety and security. And finally, of course the attempt of Russian policy-makers is to attribute to situation wider context by including other big actors such as conspiracy with the leadership of USA. Overall, the steps for enemy icon creation, used for speech content decoding and spread of hatred language are as follows:

1. Accumulating and preparing mass media for transferring the information to wide audiences for creating particular pre-text beneficial for further announcements of policy-makers;

2. Using the language of hatred by Russian policy-makers to create particular context in military forces, for preparing military opposition;

3. Creating the negative image of the country by underlining enemy's aggressive behavior towards its' own citizens;

4. Underlining the fact that enemy is not alone. By attributing allies to it, enemy is represented as a threat to whole region;

5. Comparing enemy to other historical evil forces makes situation worse. It propagandizes hatred to the wide audiences by comparing enemy to notorious wrongdoers;

6. Reminding the population about the constant threat coming from an enemy until it exists. This 
makes the population more aware of potential threat, as a result, they have increased reliance on government;

7. Showing that enemy is not alone and there is wider conspiracy makes people and policy-makers more judgmental and allows them to add more secret, existing or potential enemies to the situation.

In conclusion, we need to understand that the language of hatred is not effective in an attempt to keep one's political influence. By underlining additional threat, the policy-makers aim to prolong their governance and blame the enemy in all misfortunes happening inside the country. However, politicians need to understand that the language of hatred promotes creation of extreme nationalistic feelings and rivalry towards "enemy" cultures. This might result in creation of radical groups fighting with migrants from rival country which adds to regional tension. In my view, the creation of icon of enemy is not appropriate method to deal with political antipathies. Moreover, to propagandize several countries as the authors of conspiracy and promoting the idea of evil plans against Russia does not create an opportunity for effective peace dialogue. Even though the international organizations support the idea of peace negotiations, we need to remember that aggressive phrases and the above-mentioned politics make it very utopian idea not only to have negotiations, but also puts under the question any positive outcome from the peace negotiations. Hopefully, every policy-maker will understand that the phrases they use and the strategy they create have a wider impact on community.

\section{REFERENCES}

Agenda.Ge (2016). Investigation of Russia-Georgia war is in active phase. https://agenda.ge/en/news/2019/1229 https://agenda.ge/en/news/2016/229.

Cornell, S. E. \& Starr, S. F. (2009). The Guns of August 2008: Russia's War in Georgia (Studies of Central Asia and the Caucasus). Routledge.

Cottam, M. L., Dietz-Uhler, B., Mastors, E. (2009). Introduction to Political Psychology. Psychology Press.

Dougin, Aleksandr "Foundation of Geopolitics" http://www.4pt.su/en.

Dunlop, J. B. (2004). Aleksandr Dugin's Foundations of Geopolitics. https://tec.fsi.stanford.edu/docs/aleksandr-dugins-foundationsgeopolitics.

Embassy of Argentina in Russian Federation (2008). Interview by Minister of Foreign Affairs of the Russian Federation Sergey Lavrov to $B B C$. https://argentina.mid.ru/news/2008/-/asset_publisher/xN4dO17LPB79/content/09-08-2008-interview-by-minister-offoreign-affaires-of-the-russian-federation-sergey-lavrov-to-bbc-moscow-august-9-2008.

Faulconbridge, G. (2008). Russia's Medvedev to tackle crisis, Georgia in speech. Reuters. https://www.reuters.com/article/us-russiamedvedev/russias-medvedev-to-tackle-crisis-georgia-in-speech-idUSTRE4A11PT20081102

Illarionov, Andrei Annex of Russian Leaflet and its' translation https://www.amazon.com/Guns-August-2008-RussiasCaucasus/dp/0765625083.

Isachenkov, V. (2018). Russian PM Dmitry Medvedev warns of 'horrible' new conflict if Georgia joins NATO. National Post. https://nationalpost.com/news/world/russia-warns-of-horrible-conflict-if-georgia-joins-nato.

La Capra, D. (2001). Writing history, writing trauma. Johns Hopkins University Press.

Literary Terms (2015). Mnemonic Union. https://literaryterms.net/mnemonic/

Pasha-Robinson, L. (2013). Russia quietly moves border hundreds of yards into occupied Georgia. Independent. https://www.independent.co.uk/news/world/politics/russia-georgia-border-south-ossetia-move-hundreds-yards-occupied-natoputin-west-ukraine-a7835756.html.

President of Russia (2008). Joint Press conference with Angela Merkel. http://en.kremlin.ru/events/president/transcripts/1102.

President of Russia (2008). Statement by President of Russia Dmitry Medvedev. http://en.kremlin.ru/events/president/transcripts/1222.

President of Russia (2012). Vladimir Putin answered journalists' questions during his working trip to Leningrad Region. http://en.kremlin.ru/events/president/transcripts/16164.

President of Russia (2013). Working meeting with FSB Border Guard Service Director Vladimir Kulishov. http://en.kremlin.ru/events/president/transcripts/19039 (accessed on Feb 1)

Radio Free Europe Radio Liberty (2019). Putin Ignores Ukrainian, Georgian Presidents In New Year Greetings. https://www.rferl.org/a/putin-forgoes-ukrainian-georgian-presidents-in-new-year-greetings/30353955.html.

Zahinho (2015, February 6). Russian politician Zhirinovsky comments on war with Georgia. https://www.youtube.com/watch?v=7OCp5bCNTIk (accessed on Feb 19)

Zerubavel, E. (2003). Time maps, collective memory and the social shape of the past. Chicago: University of Chicago Press. 